Review Essay

\title{
GOOD MARX FOR STRIKING STUDENTS?
}

\begin{abstract}
ALAN SEARS
Ryerson University

Marx, Karl and Friedrich Engels. 2010. The Communist Manifesto Illustrated. Chapter One: Historical Materialism. Edited, introduced and re-imagined by George S. Rigakos. Illustrated by Red Viktor. Ottawa: Red Quill Books. ISBN 978-0-981280-72-1. Paperback: 12.50 USD. Pages: 32.

Marx, Karl and Friedrich Engels. 2011. The Communist Manifesto Illustrated. Chapter Two: The Bourgeoisie. Edited, introduced and reimagined by George S. Rigakos. Illustrated by Red Viktor. Ottawa: Red Quill Books. ISBN 978-0-981280-77-6. Paperback: 12.50 USD. Pages 34.
\end{abstract}

The test of the Communist Manifesto is whether is provides insights when read against the leading struggles of our times. The strike by Quebec students against the Charest government's $75 \%$ tuition increase is still on as I write this review, almost six months after the first students voted to walk out. This has been the largest and longest of the nine strikes waged by Quebec students since 1968.

Quebec students and their allies are waging the most sustained and creative fightback in the Canadian state against the austerity agenda promoting brutal attacks on social programs, wages, pensions, health care, public culture and education. The audacity and innovation of this movement has inspired activists across North America and around the world to wear red squares, organize pot-banging marches, and attempt to build militant and democratic forms of fightback.

The red square worn by Quebec student activists and their allies is a playful and creative symbol, combining the idea of debt ("squarely in the red") with a traditional marker of militancy (red as the colour of insurgency). It takes the red of the old left and recasts it in a new context, linked to an emerging new left with its own questions, roadmaps and icons.

In this review, I will consider whether the graphic novel version of the Communist Manifesto from Red Quill Press can do the work of the Quebec students' red square, reclaiming a classic in new terms and bridging between old and new lefts. I am not sure 
whether there has been an increased audience for the Communist Manifesto in the wake of this struggle in Quebec. There is certainly a substantial radicalization among students and their supporters, as shown by massive demonstrations, at times surpassing 300,000 marchers, as well as the resilience of the movement in the face of the Charest government's repression.

It is the nature of radicalization that it pushes activists to ask new questions about the ways the system works and how to fight it. These questions can lead people to seek out new resources to address these issues. Since it was published in 1848, the Communist Manifesto has been one of the resources most sought out by activists at times like this. But is it still? It is certainly my sense that the Manifesto has largely fallen into disuse.

This is partly because of the way people sometimes approach the Communist Manifesto as an almost sacred text, to swallow whole or to spit out completely. It is cast either as an essential foundation for contemporary activism or as an archeological remnant of flawed and totalitarian communism. This approach to the Manifesto also fits with a left that is often impatient with theoretical thinking about our movements, counterposing militant activism to reflection that is seen as "academic".

I think it is a sad loss to casually cast aside the Communist Manifesto, just as it is a serious error to look to it as a biblical document with extraordinary powers to guide our struggles. Somewhere between faith-based anti-capitalism and the rejection of serious political analysis that engages with learning from the past 200 years of struggle lies a different approach to the Manifesto, rooted in critical engagement.

The Communist Manifesto is one of those rare texts that keep being timely. Indeed, the world since the current global slump started in 2008 seems in many ways like the $3 \mathrm{D}$ remake of the Communist Manifesto. "It is enough to mention the commercial crises that by their periodical return put on its trial, each time more threateningly, the existence of the entire bourgeois [capitalist] society. In these crises a great part not only of the existing products, but also of the previously created productive forces, gets destroyed." The current global slump is one of those moments of "commercial crisis" in which we are seeing a massive destruction of human capacities, in part through an attack on the well-being of the working classes through factory shutdowns, huge reductions in the living standards of those who are employed, a dramatic increase in unemployment, and brutal cuts in social programs.

The brilliant student strike in Quebec this year is one of the emerging antiausterity resistance movements that is radicalizing new layers of people and reminding us all of the potential power to beat back the incredible attacks being launched by employers and the state; and indeed to build a better world. The Communist Manifesto could be of great value to these activists, not so much providing a road map as helping develop a set of navigational tools that can contribute to driving struggles forward over time by clarifying how key power relations actually work. 
Despite its potential usefulness, I am not sure the Communist Manifesto is getting a lot of attention these days. Of course, like many "great texts" it is fed medicinally to university students in courses, generally in a context that severs its vibrant passages from living activism. This is not what I mean by using the Manifesto, which requires critical engagement with the text, generally through group reading and discussion. It is through shared engagement with the text in relation to current struggles that people think seriously about what is there and what is missing, and how it might or might not be relevant for their activism.

In many ways, then, I am more concerned with the ways the Manifesto is used than with how it is presented. Yet presentation does matter, and particularly bringing the text into the present in thoughtful ways. The challenge is to present the Communist Manifesto so as to highlight the open-ended question of its contemporary relevance, while encouraging critical engagement with both the text itself and the history of its use.

Given this, I was really excited to see the Red Quill Press version of the Communist Manifesto drawing on the graphic novel form. Graphic novels are incredibly powerful in their ability to combine rich and suggestive images with stripped down wording to convey both individual character and wider social-political themes. There are some breath-taking moments in the first two volumes of the Red Quill series that completely justify this ambitious project. The illustration on page 16-17 of the first volume brings to life the opening line of the Manifesto, "A spectre is haunting Europe..."

This is an admirable project that shows real creativity. I love the graphic novel form in part for its ability to go beyond the linear form of telling associated with most writing by playing off image against word in such a way that the reader must actively pull it together. It can excite emotions and aesthetic senses in a way that formal writing seldom does. The best images in this book really do that, in ways that I think actually suit Marx's method of investigating social problems by unsettling what we already know to push deeper beneath the surface.

Editor George Rigakos states that the goal of this graphic edition is to "reanimate the text" (2). In general it succeeds admirably in this goal by putting Red Viktor's amazing images up against key quotes from the Manifesto. There is no way I can convey the power of these images here, and rather I simply urge you to get a copy and engage with it.

However, I fear that despite the creative form and powerful graphics, this illustrated Manifesto does not reach out to activists newer to politics in ways that it might. The first volume opens, for example, with a scene in which an older man throws books at Marx's grave. These books are historic titles reflecting the repressive character of so-called "socialist" regimes that ruled in Marx's name. Marx wakes, reads and weeps. The old man reawakens and the story begins with a clearing sky. It is intriguing, but I fear it still 
appeals more to the knowledge base and thoughts of someone like me, who already has a sense of the main players and locations.

Similarly, the short anti-Stalinist fable that begins the second volume is an interesting and valuable attempt to locate the Manifesto in relation to the history of socalled "socialism" in the Soviet Union and elsewhere. However, I fear it will not be clear to those who might most need a bridge into the text. A very high proportion of those who are active in the Quebec student strike were born after the fall of the Berlin wall in 1989. It is my sense through conversations that the question of so-called "socialist" regimes is less immediate for them (though still important) than questions about the relevance of socialist idea and practices given the rapidly changing conditions of the early $21^{\text {st }}$ century.

I fear there is a prior question that this version of the Manifesto does not address. Thoughtful young activists might ask why they should devote much effort to working through a document crafted by two European guys over 150 years ago. The fact that it was a highly influential document through much of the nineteenth and twentieth centuries, widely read if not well-understood, might mark it as worthy of historical interest, but not as a living political document. It is completely understandable that some people might think that the Manifesto should be left to rot along with the bureaucratic top-down regimes that called themselves "Communist" in Russia and Eastern Europe.

The power of the Manifesto lies specifically in its location in time and space. Marx and Engels were investigating the character of capitalism as a social system when it was still in its initial phases of development, and therefore were able to see things that are now less visible. One first entering space, we see, hear, smell, taste and feel things that quickly pass into being taken for granted. You may notice a rank smell in a room, the darkness of a cafe or the inappropriateness of a friend's new haircut on first encounter. Soon enough, however, you have adjusted and made it part of the background.

Marx and Engels were writing about capitalism at a time when workers were still asking about the rank smell of inequity that hung around their workplaces. When a social system is new, people have not yet formulated their habits and ways of knowing around it. The brilliant historian of working class struggle E.P. Thompson wrote about the way first-generation workers resisted time-discipline, the idea that you should show up at a particular place simply because a bell rang indicating it was a particular hour and therefore the start of shift. At a time when none of this seemed normal yet, Marx and Engels inquired into the essential characteristics of the emergent capitalist system.

They did not do this work alone, but in engagement with the working class movement in Paris, the most militant and activist working class the world had yet seen. The Manifesto was written as a call-out to radicals in anticipation of the revolutionary wave of 1848, which turned out to be the largest working class insurgency yet witnessed since the development of capitalism. Marx and Engels wrote attempting to equip workers 
to think through political strategies based on the possibility of overthrowing capitalism, rather than simply finding a better deal within the system.

Their keen inquiry into the workings of the system, drawing on the knowledge of capitalism that radical workers were developing through their everyday encounters with the system and their struggles for radical change, helped map key characteristics that mark the system to this day. Their analysis benefitted from first-rate analytical tools they developed through critical engagement with other radical theories, as well as from their interactions with radical workers in Paris, who could pass on the best learning passed between layers of militant activists. The discussion of class struggle, forms of exploitation, the inner workings of the capitalist system, imperialism and the oppressiveness of the family is very powerful.

In short, the Communist Manifesto is a product of its location. This is a benefit as it has insights from the establishing period of capitalism, seen through the lens of the militant workers of Paris. But it is also limited by its location, providing only a partial vision of the world at the time, let alone all that has happened since. There is a lot to address about gender, sexuality, racialization, indigeneity, the environment, representative democracy, bureaucratization, trade unions and so much more. In one reading group I was in, one woman started the discussion by asking "Why Europe?" with reference to Marx and Engels' opening quote "a spectre is haunting Europe." That question deserves a discussion that might get complicated and rich with disagreements.

I really think Red Quill Books and George Rigakos deserve a lot of credit for a gutsy and creative move. These are not easy times for radical publishing, and this is a very exciting attempt to recast a classic in visionary ways. There are some things I would have done differently, but in saying that I feel like the old fan in the back of a Neil Young concert shouting out for "Ohio," a song that was politically meaningful in the context of the shooting of students at Kent State University a long time ago. Some of my favourite passages did not get the graphic treatment I hoped for, but others far exceeded my expectations.

The full series of the illustrated manifesto will consist of four volumes, of which two were available when I started this review. Volume 3, The Proletariat, has recently been published. The entire series will also be published in French, German and Spanish. The text is abridged and rearranged thematically based on a reinterpretation by editor George Rigakos, though the passages that are included are in the original words. I fear this tends to fracture the Manifesto and make it even harder to understand as a whole, even if there are brilliant moments. Of course, I recognize that the graphic novel form requires strict limits on the word count, and that the Communist Manifesto in its original form is not well organized for new readers.

There is, however, a clear story line in the early sections of the original Manifesto, beginning with the centrality of class struggle in shaping social relations in class societies, 
then tracing out the rise of the capitalist class (the bourgeoisie) and the social system they dominate, and subsequently showing how the development of an ever-expanding working class with radical potential is central to the dynamics of capitalism itself. "What the bourgeoisie produces, above all, is its own grave-diggers."

This story line does get disrupted by the approach in these illustrated versions. I think this is a loss, though I am not sure it could be avoided given the parameters of the project. Readers of this illustrated version would also be advised to read the unabridged Manifesto, probably at the same time.

I hope these illustrated versions are widely circulated, and that they contribute to an increased use of the Communist Manifesto. There are suggestive readings in the Manifesto for turning the student struggle in Quebec into a social struggle, based on the potential solidarities arising from the way capitalism works. We should be creatively engaging with all the resources we can as we try to build a learning left grounded in radical anti-capitalism capable of gaining real social weight in this difficult moment. 